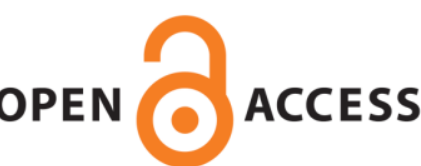

UWS Academic Portal

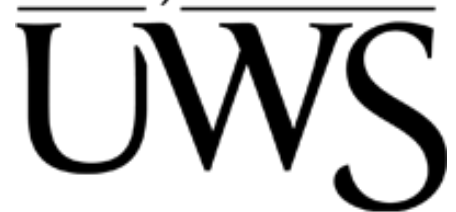

\title{
A mechanistic analysis of the influence of iron-oxidizing bacteria on antimony (V) removal from water by microscale zero-valent iron
}

Li, Yongchao; Wu, Jixin; Ren, Bozhi; Hursthouse, Andrew

Published in:

Journal of Chemical Technology and Biotechnology

DOI:

10.1002/jctb.5606

E-pub ahead of print: 09/02/2018

Document Version

Peer reviewed version

Link to publication on the UWS Academic Portal

Citation for published version (APA):

$\mathrm{Li}, \mathrm{Y}$., Wu, J., Ren, B., \& Hursthouse, A. (2018). A mechanistic analysis of the influence of iron-oxidizing bacteria on antimony $(\mathrm{V})$ removal from water by microscale zero-valent iron. Journal of Chemical Technology and Biotechnology, 93, 2527-2534. https://doi.org/10.1002/jctb.5606

\section{General rights}

Copyright and moral rights for the publications made accessible in the UWS Academic Portal are retained by the authors and/or other copyright owners and it is a condition of accessing publications that users recognise and abide by the legal requirements associated with these rights.

Take down policy

If you believe that this document breaches copyright please contact pure@uws.ac.uk providing details, and we will remove access to the work immediately and investigate your claim. 
A mechanistic analysis of the influence of iron-oxidizing bacteria on antimony (V)

removal from water by microscale zero-valent iron

\author{
Li Yongchao ${ }^{1}{ }^{*}$, Wu Jixin ${ }^{1}$, Hu Wei ${ }^{2}$, Ren Bozhi ${ }^{3}$, Hursthouse S. Andrew ${ }^{1,3,4}$ \\ ${ }^{1}$ School of Civil Engineering, Hunan University of Science and Technology, Xiangtan 411201, \\ China; \\ ${ }^{2}$ School of Life Sciences, Hunan University of Science and Technology, Xiangtan 411201, China; \\ ${ }^{3}$ Hunan Provincial Key Laboratory of Shale Gas Resource Utilization, Xiangtan 411201, China; \\ ${ }^{4}$ School of Science and Sport, University of the West of Scotland, Paisley PA1 2BE, UK
}

\begin{abstract}
BACKGROUND: Microscale zero-valent iron (mZVI) is an efficient material for removing heavy metals from water, and iron-oxidizing bacteria are the primary microorganisms responsible for iron corrosion. We investigated the effects of Sphaerotilus natans on antimony $[\mathrm{Sb}(\mathrm{V})]$ removal by mZVI using batch experiments.

RESULTS: At an initial $\mathrm{Fe}^{0}$ dose of $0.1 \mathrm{~g} \cdot \mathrm{L}^{-1}, 40 \mathrm{mg} \cdot \mathrm{L}^{-1} \mathrm{Sb}(\mathrm{V})$ was almost completely removed in an abiotic system. Although Sphaerotilus natans exhibited significant tolerance to $\mathrm{Sb}(\mathrm{V})$, its ability to adsorb $\mathrm{Sb}(\mathrm{V})$ was poor. Most importantly, the presence of Sphaerotilus natans reduced the removal rate of aqueous $\mathrm{Sb}(\mathrm{V})$ by $\mathrm{mZVI}$ by up to $39 \%$. The value of the redox potential in the biologically mediated system was lower than that in the abiotic control, indicating oxygen consumption by Sphaerotilus natans.
\end{abstract}

In the presence of Sphaerotilus natans, the main reaction products were $\mathrm{FeOOH}$ and

This article has been accepted for publication and undergone full peer review but has not been through the copyediting, typesetting, pagination and proofreading process, which may lead to differences between this version and the Version of Record. Please cite this article as doi: $10.1002 /$ jctb.5606 
$\mathrm{FeSb}_{2} \mathrm{O}_{6}$, compared to $\mathrm{Fe}_{2} \mathrm{O}_{3}$ in the abiotic system. Biomineralization of $\mathrm{Fe}^{3+}$ ions by Sphaerotilus natans may have occurred during the experiment, but it did not play a significant role in $\mathrm{Sb}(\mathrm{V})$ removal.

CONCLUSION: mZVI can be efficiently used to remove $\mathrm{Sb}(\mathrm{V})$ from water. However, the presence of Sphaerotilus natans may inhibit its removal ability, likely due to the decreased mass transfer and lower corrosion of iron.

Keywords: antimony (V); microscale zero-valent iron; iron-oxidizing bacteria;

bioinhibitory effect

\section{INTRODUCTION}

Antimony ( $\mathrm{Sb})$ is a metalloid in Group VA of the periodic table, and the $\mathrm{Sb}(\mathrm{III})$ and $\mathrm{Sb}(\mathrm{V})$ oxidation states are the most prevalent in the environment. ${ }^{1} \mathrm{Sb}$ and its compounds are hazardous to human health, with significant carcinogenicity, and $\mathrm{Sb}$ (III) is more toxic than $\mathrm{Sb}(\mathrm{V}){ }^{2}$ Antimony and its compounds are considered priority pollutants by the Council of the European Communities ${ }^{3}$ and by the United States Environmental Protection Agency. ${ }^{4}$ The World Health Organization requires that the maximum level of $\mathrm{Sb}$ in drinking water be less than $20 \mu \mathrm{g} \mathrm{\textrm {L } ^ { - 1 }}$.

Most Sb gets into the environment from anthropogenic sources such as soil runoff, road traffic emissions, fossil fuel combustion, mining, and smelting activities. ${ }^{6,7}$ The mining industry in particular produces a great quantity of mine drainage and waste residue, which can have significant impacts on the local environment. For example, due to the historic mining activities in the Kantishna Hills mining district of interior Alaska, 
$\mathrm{Sb}$ and arsenic concentrations in nearby watersheds were as high as $0.72 \mathrm{mg} \cdot \mathrm{L}^{-1}$ and $0.239 \mathrm{mg} \cdot \mathrm{L}^{-1}$, respectively. ${ }^{8}$ Because improperly treated mining and smelting wastewater was discharged into the environment, dissolved $\mathrm{Sb}$ concentrations in streams ranged from 4.58 to $29.4 \mathrm{mg} \cdot \mathrm{L}^{-1}$ in the Xikuangshan $\mathrm{Sb}$ mining area of China, ${ }^{9}$ levels that pose high health risks to the public. Consequently, different methods for treating antimony-contaminated water have recently been developed.

Adsorption is one of the most effective techniques for the removal of $\mathrm{Sb}$ from aqueous solution owing to its high efficiency, simplicity, and rapid response. ${ }^{10,11}$ Commonly used adsorbents for Sb include nanomaterials, activated carbon, bentonite, and iron-based oxides and residues. ${ }^{12,13}$ However, most of these materials are produced through complicated chemical methods or require modifications, and thus the treatment costs for significant quantities of Sb-containing wastewater are high. Available zero-valent iron (ZVI) has been shown to be an efficient and cost-effective material for removing heavy metals, nitrates, hydrocarbons from water. ${ }^{14-16}$ Under aerobic conditions, $\mathrm{Fe}^{0}$ is oxidized by $\mathrm{O}_{2}$ in water, yielding $\mathrm{Fe}^{2+}$ ions. The resulting $\mathrm{Fe}^{2+}$ can be further oxidized to $\mathrm{Fe}^{3+}$ ions, and then hydrolyzed to form iron oxide precipitates. The contaminants are therefore trapped within the precipitates and removed from the water. ${ }^{17} \mathrm{Sb}(\mathrm{V})$ in model solution can be immobilized by ZVI, and a maximum of 18.1 $\mathrm{mg} \mathrm{Sb}(\mathrm{V}) \cdot \mathrm{g}^{-1} \mathrm{ZVI}$ has been achieved. The incorporation of $\mathrm{Sb}(\mathrm{V})$ into the structure of iron (hydr)oxides has been evaluated using X-ray absorption fine structure spectroscopy analysis. ${ }^{18}$ The influence of tartrate and a weak magnetic field on the removal of Sb(III) 
by ZVI has also been investigated with batch and semi-continuous reactors. ${ }^{19}$ Nanoscale zero-valent iron (nZVI) has also drawn attention as an effective approach for removing $\mathrm{Sb}$ from solution. ${ }^{20,21}$ The influence of a range of processing parameters on $\mathrm{Sb}$ removal by $\mathrm{Fe}^{0}$ has been systematically investigated, including contact time, solution $\mathrm{pH}$, initial $\mathrm{Sb}$ concentration, co-existing ions, and the effects of weak magnetic fields. In addition to these physical and chemical factors, the high abundance of microorganisms in the aqueous environment may significantly influence the performance of ZVI in water treatment systems. Microorganisms can attach to iron surfaces and cause microbiologically influenced corrosion. ${ }^{22}$ Furukawa et al. ${ }^{23}$ and Wilkin et al. ${ }^{24}$ demonstrated that some iron corrosion products, including iron hydroxides, oxy-hydroxides, and green rusts, are beneficial in arsenic removal from water. Nonetheless, An et al. ${ }^{25}$ reported that the presence of hydrogenotrophic bacteria in water generated a lepidocrocite layer on iron surfaces and decreased the nitrate removal rate of nZVI. The influence of microorganismal activity on the removal of Sb by ZVI remains unclear.

Aerobic iron-oxidizing bacteria (IOB) constitute one of the major iron corrosion pathways in surface environments. They attach to the surface of iron-rich materials and generate biological iron oxide minerals. ${ }^{26,27}$ In an aerobic environment, IOB can oxidize ferrous ions and deposit iron hydroxides extracellularly. ${ }^{28}$ Sphaerotilus natans, which belongs to the IOB consortia, exists naturally in ecological communities found in heavily polluted freshwater and activated sludge systems in the form of superficial 
mucilage layers. ${ }^{29,30}$ Starosvetsky et $a l .{ }^{31}$ isolated IOB from rust deposits on a clogged carbon steel heat exchanger in Israel, and the primary strain was also identified as a Sphaerotilus sp. In addition, living and lyophilized Sphaerotilus natans can be used to treat heavy metal cations by biosorption. ${ }^{32}$ When considering the potential of ZVI in the treatment of $\mathrm{Sb}$-contaminated wastewater, the impacts of biofilms in the treatment system on long-term performance must be considered. There is little previously published information on the removal of $\mathrm{Sb}$ from water by ZVI in the presence of microorganisms, especially Sphaerotilus natans.

$\mathrm{Sb}(\mathrm{V})$ is the dominant form of $\mathrm{Sb}$ in water at most environmentally relevant $\mathrm{pH}$ levels; ${ }^{1}$ therefore, it was selected as the target pollutant in this study. The main objectives of this paper were to (1) investigate $\mathrm{Sb}(\mathrm{V})$ removal by microscale zero-valent iron (mZVI) in abiotic systems; (2) assess the $\mathrm{Sb}(\mathrm{V})$ adsorption ability of Sphaerotilus natans and its biomineralization; (3) study the $\mathrm{Sb}(\mathrm{V})$ removal ability of ZVI in the presence of Sphaerotilus natans; and (4) explore the mechanism of the bioinhibitory effect of Sphaerotilus natans on $\mathrm{Sb}(\mathrm{V})$ remediation with ZVI.

\section{MATERIALS AND METHODS}

\section{Cultivation of microorganisms}

In this study, lyophilized Sphaerotilus natans NBRC\#13543 was purchased from Beijing Yuding Xinjie Technology, Ltd. (Beijing, China). The cultivation medium contained polypeptone $\left(10 \mathrm{~g} \cdot \mathrm{L}^{-1}\right)$, yeast powder $\left(2 \mathrm{~g} \cdot \mathrm{L}^{-1}\right)$, agar $\left(15 \mathrm{~g} \cdot \mathrm{L}^{-1}\right)$, magnesium sulfate heptahydrate $\left(1 \mathrm{~g} \cdot \mathrm{L}^{-1}\right)$, and ammonium iron citrate $\left(10 \mathrm{mg} \cdot \mathrm{L}^{-1}\right)$. The culture 
medium was autoclaved at $121^{\circ} \mathrm{C}$ for $20 \mathrm{~min}$ after the initial $\mathrm{pH}$ was adjusted to 7.0. After cultivation for two consecutive generations, the strain grew normally. Colonies on plates were sampled with a sterile loop, inoculated in $250-\mathrm{mL}$ conical flasks containing liquid culture medium, and then incubated at $30^{\circ} \mathrm{C}$. The biomass growth was monitored by measuring the optical density (OD), and the growth curve of Sphaerotilus natans was investigated.

\section{Effects of dissolved oxygen (DO) and $\mathrm{pH}$ on $\mathrm{Sb}(\mathrm{V})$ removal by $\mathrm{ZVI}$ in abiotic systems}

$\mathrm{An} \mathrm{Sb}(\mathrm{V})$ stock solution with an $\mathrm{Sb}$ concentration of $500 \mathrm{mg} \cdot \mathrm{L}^{-1}$ was prepared by dissolving $\mathrm{KSb}(\mathrm{OH})_{6}$ in $2 \mathrm{~mol} \cdot \mathrm{L}^{-1} \mathrm{HCl}$ solution. Experimental solutions of $\mathrm{Sb}(\mathrm{V})$ were obtained by diluting the stock solution with deionized (DI) water. mZVI was first added to a conical flask containing $200 \mathrm{~mL}$ of $40 \mathrm{mg} \cdot \mathrm{L}^{-1} \mathrm{Sb}(\mathrm{V})$ solution and then covered with a ventilated rubber stopper. All flasks were placed on a rotary shaker at $100 \mathrm{r} \cdot \mathrm{min}^{-1}$ at

$30^{\circ} \mathrm{C}$. At timed intervals, samples were taken from the suspension, filtered through $0.45-\mu \mathrm{m}$ membrane filters, and analyzed for total $\mathrm{Sb}$ remaining in the aqueous phase. Additionally, the redox potential (Eh) of the solution was monitored as the reaction progressed.

To test the effects of dissolved oxygen (DO) on $\mathrm{Sb}(\mathrm{V})$ removal, a fixed amount of mZVI was added to serum bottles after the initial $\mathrm{Sb}(\mathrm{V})$ solution was purged with $\mathrm{N}_{2}$ gas for $2 \mathrm{~h}$. Then, the bottles were sealed with Teflon septa and aluminum crimps, followed by mixing at $100 \mathrm{r} \cdot \mathrm{min}^{-1}$ on a rotary shaker at $30^{\circ} \mathrm{C}$. At timed intervals, the $\mathrm{Sb}$ 
concentration in the solution was determined as above. The normalized residual concentration $\left(\mathrm{C} / \mathrm{C}_{0}\right)$ was used to describe the removal kinetics.

To test the effects of solution $\mathrm{pH}$ on $\mathrm{Sb}(\mathrm{V})$ adsorption, the initial $\mathrm{pH}$ of $\mathrm{Sb}(\mathrm{V})$ solutions was pre-adjusted to $5.0,6.0,7.0$, and 8.0 with $1.0 \mathrm{~mol} \cdot \mathrm{L}^{-1} \mathrm{HCl}$ or $1.25 \mathrm{~mol} \cdot \mathrm{L}^{-1}$ $\mathrm{NaOH}$. Then, mZVI was added, and the conical flasks were covered with ventilated rubber stoppers. The analysis of residual Sb during the process was as described above.

\section{$\mathrm{Sb}(\mathrm{V})$ adsorption tests with Sphaerotilus natans biomass}

After cultivation in liquid culture medium for $12 \mathrm{~h}, 5 \mathrm{~mL}$ of Sphaerotilus natans suspension was added to $250-\mathrm{mL}$ conical flasks containing $195 \mathrm{~mL} \mathrm{Sb}(\mathrm{V})$ solution. The initial solution $\mathrm{pH}$ was 7.0 , and the $\mathrm{Sb}(\mathrm{V})$ concentration was $40 \mathrm{mg} \cdot \mathrm{L}^{-1}$. The flasks were placed on a rotary mixer at $30^{\circ} \mathrm{C}$. The $\mathrm{OD}$ at $500 \mathrm{~nm}\left(\mathrm{OD}_{500}\right)$ and residual $\mathrm{Sb}(\mathrm{V})$ concentrations in solution were monitored during the subsequent reaction.

\section{$\mathrm{Sb}(\mathrm{V})$ removal ability of $\mathrm{mZVI}$ in the presence of Sphaerotilus natans}

Aliquots $(5,10,15$, and $20 \mathrm{~mL})$ of Sphaerotilus natans cell suspension $\left(1.6 \times 10^{9} \mathrm{CFU}\right.$ $\mathrm{mL}^{-1}$ ) that were cultivated for $12 \mathrm{~h}$ and $0.02 \mathrm{~g}$ ZVI were added to flasks containing an aqueous solution of $\mathrm{Sb}(\mathrm{V})$ without nutrients. The initial $\mathrm{Sb}(\mathrm{V})$ concentration in all flasks was approximately $40 \mathrm{mg} \cdot \mathrm{L}^{-1}$, and the initial $\mathrm{pH}$ was 7.0 . The flasks were covered with ventilated rubber stoppers and placed on a rotary shaker at $100 \mathrm{r} \cdot \mathrm{min}^{-1}$ at $30^{\circ} \mathrm{C}$. Sphaerotilus natans biomass, residual $\mathrm{Sb}(\mathrm{V})$ concentration, and Eh value in solution were analyzed as the reaction progressed. After the reaction, the morphologies and main chemicals of the precipitates were analyzed. 


\section{Characterization}

The particle size and morphology of fresh mZVI and generated products were examined using scanning electron microscopy (SEM, JSM-6380LV, JEOL, Japan). The chemical composition and crystal structures of the precipitates after reaction were characterized using X-ray diffraction (XRD, D8 Advance, Bruker, Germany). Functional groups on the surface of samples were measured by Fourier transform infrared spectrometry (FTIR, Nicolet 6700, USA) using the standard $\mathrm{KBr}$ disk method. Sphaerotilus natans in suspension was imaged by high resolution scanning electron microscopy (HRSEM, SU8010, Hitachi, Japan).

\section{Analytical methods}

Total $\mathrm{Sb}$ in solution was analyzed using a flame atomic absorption spectrophotometer (AA-7001, East \& West Analytical Instruments, Inc., Beijing), with suitable matrix-matched standards and replicates. The Eh value of the solution was determined using a BPP-920 ORP meter (BELL Analytical Instruments Co., Ltd., Dalian, China). The $\mathrm{pH}$ values were measured using a basic PB-10 meter (Sartorius, Germany). The number of colony-forming units $(\mathrm{CFU})$ in the solution was determined by surface plating at appropriate dilutions. ${ }^{33}$ All experiments were carried out in triplicate, and the averages are reported.

\section{RESULTS AND DISCUSSION}

\section{Removal of Sb(V) by mZVI in abiotic systems}

Effects of $\mathrm{DO}$ on $\mathrm{Sb}(\mathrm{V})$ removal by ZVI 
Oxygen is a major electron acceptor in reduction systems, and it plays a complicated role in the mZVI reaction. The presence of $\mathrm{O}_{2}$ in the iron-water system has been shown to increase the reduction of monochloroacetic and dichloroacetic acid, and to decrease the removal efficiency of bromate and nitrate. ${ }^{34}$ However, investigations of the effects of $\mathrm{O}_{2}$ on $\mathrm{Sb}(\mathrm{OH})_{6}{ }^{-}$removal have been limited.

The removal of $\mathrm{Sb}(\mathrm{V})$ from water solution using mZVI without $\mathrm{N}_{2}$ purging is shown in Fig. 1a. At initial doses of $0.05,0.1,0.15$, and $0.25 \mathrm{~g} \cdot \mathrm{L}^{-1} \mathrm{Fe}$, a total of 76.2 , $90.6,95.7$ and $100 \%$ of $40 \mathrm{mg} \cdot \mathrm{L}^{-1} \mathrm{Sb}(\mathrm{V})$ were removed within $24 \mathrm{~h}$, respectively. The removal rates then gradually increased, finally reaching 84.6, 99, 100, and 100\%, respectively. Increasing the amount of mZVI resulted in faster and more extensive removal of $\mathrm{Sb}(\mathrm{V})$ from the aqueous phase, mainly because the increased dose of $\mathrm{Fe}$ would increase the total surface area and thus the available active sites for $\mathrm{Sb}(\mathrm{V})$ sorption. ${ }^{35}$ The Eh value in solution was examined during the experiment, as shown in Fig. 1b. It decreased sharply from $421-497 \mathrm{mV}$ to $99-150 \mathrm{mV}$ after $12 \mathrm{~h}$, followed by a slow increase, reaching $150-320 \mathrm{mV}$ at the end of the experiment. DO depletion may be an important reason for this Eh decrease in solution. Li et al. ${ }^{18}$ suggested that the main mechanism for $\mathrm{Sb}(\mathrm{V})$ removal by $\mathrm{ZVI}$ was the incorporation of $\mathrm{Sb}(\mathrm{V})$ into the structure of iron (hydr)oxides from iron corrosion. The $\mathrm{Fe}^{0}$ in water was oxidized by $\mathrm{O}_{2}$, producing $\mathrm{Fe}^{2+}$, which can be subsequently oxidized to $\mathrm{Fe}^{3+}$ and generate iron oxides. Therefore, much of the $\mathrm{O}_{2}$ was consumed as result of iron corrosion, according to Eqs. $(1-3)::^{17,36}$ 


$$
\begin{aligned}
& \mathrm{Fe}^{0}+\mathrm{H}_{2} \mathrm{O}+1 / 2 \mathrm{O}_{2} \rightarrow \mathrm{Fe}^{2+}+2 \mathrm{OH}^{-} \\
& \mathrm{Fe}^{2+}+1 / 2 \mathrm{H}_{2} \mathrm{O}+1 / 4 \mathrm{O}_{2} \rightarrow \mathrm{Fe}^{3+}+\mathrm{OH}^{-} \\
& \mathrm{Fe}^{3+}+3 \mathrm{H}_{2} \mathrm{O} \rightarrow \mathrm{Fe}(\mathrm{OH})_{3}+3 \mathrm{H}^{+} .
\end{aligned}
$$

In addition, $\mathrm{ZVI}\left(\mathrm{Fe}^{2+} / \mathrm{Fe}^{0}\right)$, with a standard reduction potential of $-0.44 \mathrm{~V},{ }^{37}$ can reduce any species with a potential lower than that of Fe. The primary $\mathrm{Sb}(\mathrm{V})$ species, $\left(\mathrm{Sb}(\mathrm{OH})_{6}{ }^{-}\right)$, has a standard electric potential of $+0.76 \mathrm{~V},{ }^{38}$ and the overall electrochemical reaction is thermodynamically favorable. Dorjee et $a l .^{20}$ demonstrated that a fraction of the $\mathrm{Sb}(\mathrm{V})$ species was reduced to $\mathrm{Sb}(\mathrm{III})$ when $\mathrm{Sb}(\mathrm{V})$ was chemisorbed and interacted with the "FeOOH" layer on the nZVI surface. Although the reduction rate of $\mathrm{mZVI}$ was not as fast as that of $\mathrm{nZVI}$, the reduction of $\mathrm{Sb}(\mathrm{V})$ by $\mathrm{mZVI}$ to $\mathrm{Sb}(\mathrm{III})$ species may have occurred. In general, as the reduction and precipitate reaction progressed, the Eh value decreased. ${ }^{39,40}$ After $24 \mathrm{~h}$, the $\mathrm{Sb}(\mathrm{V})$ removal reaction slowed, and the Eh values in solution increased again, which was thought to be due to the increase in DO in solution owing to $\mathrm{O}_{2}$ diffusion.

After the $\mathrm{Sb}(\mathrm{V})$ solution was purged with $\mathrm{N}_{2}$, the dynamic process of $\mathrm{Sb}(\mathrm{V})$ removal with mZVI was studied. As shown in Fig. 2, at the initial Fe doses of 0.05, 0.1, 0.15 , and $0.25 \mathrm{~g} \cdot \mathrm{L}^{-1}, 78,83,84.9$, and $93.2 \%$ of $\mathrm{Sb}(\mathrm{V})$ was removed by $\mathrm{mZVI}$ after $96 \mathrm{~h}$ of the reaction process, respectively. The $\mathrm{Sb}(\mathrm{V})$ removal rate by $\mathrm{mZVI}$ was reduced by $6.6-16 \%$. This was likely due to the absence of soluble $\mathrm{Fe}^{2+}$, which is normally produced by the anaerobic corrosion of $\mathrm{Fe}^{0}$, according to Eq. $(4)^{36}$ :

$$
\mathrm{Fe}^{0}+2 \mathrm{H}_{2} \mathrm{O} \rightarrow \mathrm{Fe}^{2+}+\mathrm{H}_{2}+2 \mathrm{OH}^{-}
$$


Thus, the formation of iron oxides, which can more effectively adsorb $\mathrm{Sb}(\mathrm{V})$, cannot occur unless there is enough $\mathrm{O}_{2}$ in the water. This is similar to aqueous $\mathrm{Cr}(\mathrm{VI})$ removal kinetics in that mZVI was found to be greater under oxic than under anoxic conditions due to the formation of iron oxides, even though $\mathrm{Cr}(\mathrm{VI})$ was reduced to $\mathrm{Cr}$ (III) by $\mathrm{Fe}^{0}$ under both conditions. ${ }^{41}$ Overall, the presence of DO in solution has a significant benefit for the removal of $\mathrm{Sb}(\mathrm{V})$ by $\mathrm{mZVI}$.

Effects of solution $\mathrm{pH}$ on $\mathrm{Sb}(\mathrm{V})$ removal

We next investigated the influence of $\mathrm{pH}$ on the removal of $\mathrm{Sb}(\mathrm{V})$ by $\mathrm{mZVI}$ under aerated conditions. As shown in Fig. 3a, 100, 100, 99, and $89.79 \%$ of $40 \mathrm{mg} \cdot \mathrm{L}^{-1} \mathrm{Sb}(\mathrm{V})$ was removed by $0.1 \mathrm{~g} \cdot \mathrm{L}^{-1} \mathrm{mZVI}$ at the initial $\mathrm{pH}$ levels of 5.0, 6.0, 7.0, and 8.0, respectively. The $\mathrm{pH}$ slowly increased as the reaction progressed, although no acid or alkali was added to maintain the $\mathrm{pH}$ throughout the process. After $96 \mathrm{~h}$, the final $\mathrm{pH}$ ranged from 7.45 to 8.81 (Fig. 3b). Thus, the removal of $\mathrm{Sb}(\mathrm{V})$ by mZVI was more effective at lower $\mathrm{pH}$ values. This was because decreased $\mathrm{pH}$ accelerated the corrosion of iron and the generation of iron oxides. As the conditions of Sb mine drainage in China fall within the weak acid to weak base $\mathrm{pH}$ range, subsequent tests of $\mathrm{Sb}(\mathrm{V})$ removal were carried out at a $\mathrm{pH}$ of 7.0.

\section{Adsorption of $\mathrm{Sb}(\mathrm{V})$ by Sphaerotilus natans biomass}

Growth tests of Sphaerotilus natans

Preliminary tests were carried out to study the growth behavior of Sphaerotilus natans in liquid culture medium at different initial $\mathrm{pH}$ values. The fastest growth was obtained 
at an initial $\mathrm{pH}$ of 7.0, and the growth of the strain was poor when the $\mathrm{pH}$ was below 6.0 (Fig. S1). Solisio et al. ${ }^{29}$ suggested that the growth of Sphaerotilus natans cells was negligible below $\mathrm{pH}$ 6.0. The lag phase of biomass growth lasted for less than $6 \mathrm{~h}$. Once they adapted to culture medium with an initial $\mathrm{pH}$ of 7.0, the cells grew rapidly, and the maximum $\mathrm{OD}_{500}$ reached 1.41 after 36 days of cultivation.

Bioadsorption of $\mathrm{Sb}(\mathrm{V})$ by Sphaerotilus natans from solution

After $5 \mathrm{~mL}$ of cell suspension was added to $\mathrm{Sb}(\mathrm{V})$ solution, we investigated the ability of Sphaerotilus natans to bioadsorb during culture growth. As shown in Fig. 4, the initial $\mathrm{OD}_{500}$ of the solution was 1.09 . It deceased to 0.94 after $6 \mathrm{~h}$ as a result of the adaptation of the bacteria, and gradually increased during the next treatment. Therefore, Sphaerotilus natans exhibited significant tolerance to $\mathrm{Sb}(\mathrm{V})$. Although there was some fluctuation, the removal rate of $\mathrm{Sb}(\mathrm{V})$ was only $5.4 \%$ at the end of experiment. It has been previously demonstrated that Sphaerotilus natans efficiently adsorbs $\mathrm{Cu}^{2+}$ and $\mathrm{Cd}^{2+}$ ions. ${ }^{42}$ Qin et $a l .{ }^{43}$ showed that electrostatic attraction played a major role in the sorption process, despite the presence of active $-\mathrm{CONH}_{2}$ and $-\mathrm{OH}$ groups on the cell surface. In our study, Sphaerotilus natans showed low adsorption capacity toward $\mathrm{Sb}(\mathrm{V})$, which may have been due to weak electrostatic attraction between $\mathrm{Sb}(\mathrm{OH})_{6}{ }^{-}$and the negatively charged microorganisms. ${ }^{44}$

\section{$\mathrm{Sb}(\mathrm{V})$ removal from water by $\mathrm{mZVI}$ in the presence of Sphaerotilus natans}

Fig. 5 shows the influence of Sphaerotilus natans on $\mathrm{Sb}(\mathrm{V})$ removal by $\mathrm{mZVI}$ and the corresponding total number of CFU and Eh values in a solution with an initial $\mathrm{pH}$ of 7.0. 
As shown in Fig. 5a, with additions of 5, 10, 15, and $20 \mathrm{~mL}$ of biomass, the final $\mathrm{Sb}(\mathrm{V})$ removal rates were approximately $85.4,71.7,62.4$, and $60.3 \%$, respectively. Under identical reaction conditions, the removal rate of $\mathrm{Sb}(\mathrm{V})$ by $\mathrm{mZVI}$ in the absence of Sphaerotilus natans was approximately 99\%. Thus, the removal of $\mathrm{Sb}(\mathrm{V})$ decreased by 13.6-38.7\% upon the addition of the Sphaerotilus natans suspension. Previous experiments have indicated that Sphaerotilus natans alone has little capacity to adsorb $\mathrm{Sb}(\mathrm{V})$. Thus, the presence of Sphaerotilus natans seriously inhibited the removal efficiency of $\mathrm{Sb}(\mathrm{V})$ by $\mathrm{mZVI}$. Moreover, the removal of $\mathrm{Sb}(\mathrm{V})$ decreased when the initial biomass increased. This likely occurred because a large mass of Sphaerotilus natans would decrease the exposure of the iron surface area, negatively affecting mass transfer. The previous experiment also indicated that moderate DO was important for $\mathrm{Sb}(\mathrm{V})$ removal by mZVI and that the DO was likely to decrease as $\mathrm{O}_{2}$ was consumed by aerobic Sphaerotilus natans.

The total number of bacterial colonies was monitored during the experiment to assess the growth rate of Sphaerotilus natans in the presence of mZVI. As shown in Fig. $5 \mathrm{~b}$, the total number of CFUs in solution ranged from 0.38 to $1.5 \times 10^{8} \mathrm{CFU} \mathrm{mL}^{-1}$ after the addition of Sphaerotilus natans, and then increased to $0.9-4.0 \times 10^{8} \mathrm{CFU} \mathrm{mL}^{-1}$ after cultivation for $12 \mathrm{~h}$. Because Sphaerotilus natans is an oligotrophic bacterium and due to its strong tolerance to $\mathrm{Sb}(\mathrm{V})$, its adaptive phase was relatively short. After $24 \mathrm{~h}$, the cells were nearly in the stationary growth phase. The total number of CFUs in solution with the initial addition of $20 \mathrm{~mL}$ of biomass was greater than that in solutions with 
initial additions of 5,10 , and $15 \mathrm{~mL}$ of biomass. Meanwhile, the number of cells in the $\mathrm{Sb}(\mathrm{V})$ solution containing $5 \mathrm{~mL}$ of biomass decreased rapidly due to insufficient nutrients. After $24 \mathrm{~h}$ of rapid growth of Sphaerotilus natans, the corresponding Eh value in solution was greatly reduced as a result of the high consumption of the limited $\mathrm{O}_{2}{ }^{45}$ It ultimately declined to approximately $10-52 \mathrm{mV}$ (Fig. 5c), much lower than the Eh value of the abiotic solution.

\section{Mechanism analysis}

SEM characterization of the products from abiotic and biotic systems

Fresh mZVI (Fig. 6a) before a reaction had an irregular spherical shape with a smooth surface, and a diameter ranging from 10 to $40 \mu \mathrm{m}$. However, after reaction with $\mathrm{Sb}(\mathrm{V})$ solution without purging $\mathrm{N}_{2}$, the product in the abiotic system (Fig. 6b) was not uniform in size, and many small particulates with rough surfaces were formed. In the presence of $10 \mathrm{~mL}$ Sphaerotilus natans, the product surface recovered and exhibited a clustered shape (Fig. 6c and d) in the biologically mediated system, indicating that different products may have been generated in these two systems.

XRD characterization of products after reaction

Powder XRD was used to further investigate the differences between the products generated in the biological and abiotic reaction systems. As presented in Fig. 7a, solid products in the abiotic reaction system without $\mathrm{N}_{2}$ purging exhibited broad diffraction peaks at approximately $32,41.5,54$, and $63.5^{\circ}$, a feature of amorphous $\mathrm{Fe}_{2} \mathrm{O}_{3}{ }^{46}$ No diffraction peaks for Sb-specific phases were detected in the product, as this was likely 
to be at low levels and may have been non-crystalline or sorbed into other phases. Compared with the abiotic reaction system, the amorphous $\mathrm{Fe}_{2} \mathrm{O}_{3}$ pattern of the product in the biological reaction systems was much weaker. However, the potential presence of $\mathrm{FeOOH}$ was indicated by the diffraction peaks at $2 \theta$ values of 36.6 and $53.2^{\circ} .47,48$ Strong diffraction peaks were observed at 43.1 and $81.5^{\circ}$, which was identified as $\mathrm{FeSb}_{2} \mathrm{O}_{6}$ with JCPDS Card No. 07-0349. The presence of $\mathrm{Fe}(\mathrm{II})$ in $\mathrm{FeSb}_{2} \mathrm{O}_{6}$ was probably due to the growth of Sphaerotilus natans resulting in insufficient $\mathrm{O}_{2}$ and inhibiting the oxidization of ferrous ions. In addition, the characteristic diffraction peaks of $\mathrm{Fe}^{0}$ were not observed, probably because the surface of mZVI was covered by a thick layer of precipitate.

FTIR characterization of the products

After reaction with $\mathrm{Sb}(\mathrm{V})$ solution, the product was also characterized by FTIR. As shown in Fig. 8, the absorption peaks observed at approximately $3300 \mathrm{~cm}^{-1}$ and 1640 $\mathrm{cm}^{-1}$ in all three samples were assigned to the bond stretching of $\mathrm{O}-\mathrm{H}$ and the bending vibration of adsorbed water, respectively. ${ }^{49}$ The broad peak ranging from 700 to 400 $\mathrm{cm}^{-1}$ observed in all samples may be assigned to the $\mathrm{Fe}-\mathrm{O}$ bond of iron oxides or $\mathrm{Sb}-\mathrm{O}$ bending vibrations, ${ }^{21}$ indicating the presence of interactions between $\mathrm{Fe}-\mathrm{O}$ bonds with $\mathrm{Sb}(\mathrm{V})$. In the FTIR spectrum of the product in the biological system, the peak appearing at $1540 \mathrm{~cm}^{-1}$ was closely related to the $\mathrm{N}-\mathrm{H}$ from proteins, and the peak at $1380 \mathrm{~cm}^{-1}$ may be attributed to the $\mathrm{C}-\mathrm{H}$ bending vibrations, suggesting the presence of biomass. ${ }^{50}$ Characterization of Sphaerotilus natans in suspension after reaction 
At the end of the experiment, the suspension that contained the biomass was collected and characterized with HRSEM (Fig. 9a and b). After cultivation in $\mathrm{Sb}(\mathrm{V})$ solution for $96 \mathrm{~h}$, the cells still maintained a short rod shape. There were some small deposits near the bacteria, and also larger porous flocs that covered several cells. Aside from Leptothrix, Crenothrix, Clonothrix, and Hyphomicrobium sp., Sphaerotilus sp. is one of the best-documented examples of IOB in aquatic systems, which can bind and precipitate ferric iron non-specifically onto their cell surfaces to form precipitates. $^{31,51}$ $\mathrm{Sun}^{52}$ found that the mineralization and crystallization of $\mathrm{Fe}(\mathrm{OH})_{3}$ gel occurred both inside and outside Sphaerotilus sp. cells in a solution containing $0.01 \mathrm{~mol} \cdot \mathrm{L}^{-1} \mathrm{Fe}^{3+}$. The main product was weak crystalline akaganeite $(\beta-\mathrm{FeOOH})$ nanoparticles. Moreover, the naturally biomineralized iron oxides had a strong adsorptive capacity to $\mathrm{Cr}(\mathrm{VI})$. The morphology and structure of iron (hydr)oxides formed through the mineralization of $\mathrm{Fe}(\mathrm{OH})_{3}$ gel varied with the ingredients and concentrations of organic matrices.

During the reaction with $\mathrm{Sb}(\mathrm{V})$ solution, the corrosion of $\mathrm{mZVI}$ produced $\mathrm{Fe}^{3+}$ ions that were precipitated by Sphaerotilus natans. This is supported by the XRD data, which demonstrated the generation of $\mathrm{FeOOH}$ in the presence of Sphaerotilus natans in solution. Therefore, we can conclude that biomineralization of Sphaerotilus natans actually occurred in the experiment. Although different kinds of iron oxides or hydroxides have recently been widely used to remove $\mathrm{Sb}$ from water, ${ }^{13}$ the $\mathrm{Sb}(\mathrm{V})$ removal ability of mZVI was seriously reduced in the presence of Sphaerotilus natans, indicating that the adsorption ability of biologically formed iron oxides did not play a 
major role in $\mathrm{Sb}(\mathrm{V})$ removal.

\section{CONCLUSIONS}

ZVI has great potential in the environmental remediation of metal ions in water. However, the removal of $\mathrm{Sb}(\mathrm{V})$ by $\mathrm{ZVI}$ in the presence of microorganisms was not previously well understood. The effects of Sphaerotilus natans on $\mathrm{Sb}(\mathrm{V})$ removal by mZVI were investigated for the first time in this study. Our results indicated that although Sphaerotilus natans had some adsorption ability towards $\mathrm{Sb}(\mathrm{V})$, the presence of Sphaerotilus natans seriously inhibited the ability of mZVI to remove $\mathrm{Sb}(\mathrm{V})$, probably because the mass transfer and corrosion of iron were lowered. The biomineralization of $\mathrm{Fe}^{3+}$ ions by Sphaerotilus natans may have occurred during the experiment, but adsorption to biogenic minerals did not play a primary role in $\mathrm{Sb}(\mathrm{V})$

removal. The main product in the abiotic system was $\mathrm{Fe}_{2} \mathrm{O}_{3}$, whereas $\mathrm{FeOOH}$ and $\mathrm{FeSb}_{2} \mathrm{O}_{6}$ were produced in the presence of Sphaerotilus natans.

\section{ACKNOWLEDGEMENTS}

This work was supported by the National Nature Science Foundation of China (No. 51504094 and 31401943). Andrew S. Hursthouse acknowledges the support of Hunan Provincial Government and Hunan University of Science \& Technology through the High End Expert Scholarship.

\section{REFERENCES}

1 Filella M, Belzile N, Chen YW, Antimony in the environment: A review focused on natural waters. II. Relevant solution chemistry. Earth Sci Rev 59: 265-285 (2002). 
2 Seiler HG, Sigel A, Sigel H, Handbook on metals in clinical and analytical chemistry. Marcel Dekker, New York (1994).

3 Council of the European Communities, Council Directive 76/464/EEC of 4 May 1976 on pollution caused by certain dangerous substances discharged into the aquatic environment of the community. Official Journal L 129: 23-29 (1976).

4 United States Environmental Protection Agency, Water Related Fate of the 129 Priority Pollutants. Office of Water Planning and Standards. Washington, DC (1979).

5 WHO. Guidelines for drinking-water quality: volume 2. Health criteria and other supporting information 2nd ed, World Health Organization, Geneva (1996).

6 Filella M, Belzile N, Chen YW, Antimony in the environment: a review focused on natural waters I. Occurrence. Earth-Science Rev 57: 125-176 (2002).

7 Li YC, Hu XX, Ren BZ, Treatment of antimony mine drainage: challenges and opportunities with special emphasis on mineral adsorption and sulfate reducing bacteria. Water Sci Technol 73: 2039-2051 (2016).

8 Ritchie VJ, Ilgen AG, Mueller SH, Trainor TP, Goldfarb RJ, Mobility and chemical fate of antimony and arsenic in historic mining environments of the Kantishna Hills district, Denali National Park and Preserve, Alaska. Chem Geol 335: 172-188 (2013).

9 He MC, Wang XQ, Wu FC, Fu ZY, Antimony pollution in China. Sci Total Environ 421: 41-50 (2012). 
10 Luo JM, Luo XB, Crittenden J, Qu JH, Bai YH, Peng Y, Li JH, Removal of antimonite $(\mathrm{Sb}(\mathrm{III}))$ and antimonate $(\mathrm{Sb}(\mathrm{V}))$ from aqueous solution using carbon nanofibers that are decorated with zirconium oxide $\left(\mathrm{ZrO}_{2}\right)$. Environ Sci Technol 49: 11115-11124 (2015).

11 Yang WC, Tang QZ, Wei JM, Ran YJ, Chai LY, Wang HY, Enhanced removal of $\mathrm{Cd}(\mathrm{II})$ and $\mathrm{Pb}(\mathrm{II})$ by composites of mesoporouscarbon stabilized alumina. Appl Surf Sci 369: 215-223 (2016).

12 Iqbal M, Saeed A, Edyvean RGJ, Bioremoval of antimony(III) from contaminated water using several plant wastes: optimization of batch and dynamic flow conditions for sorption by green bean husk (Vigna radiata). Chem Eng $J$ 225: $192-$ 201 (2013).

13 Xu W, Liu RP, Qiu JH, Peng RM, Adsorption of antimony(V) onto Mn(II)-enriched surfaces of manganese oxide and Fe-Mn binary oxide. Chemosphere 138: 616-624 (2015).

14 Guo XJ, Yang Z, Dong HY, Guan XH, Ren QD, Lv XF, Jin X, Simple combination of oxidants with zero-valent-iron (ZVI) achieved very rapid and highly efficient removal of heavy metals from water. Water Res 88: 671-680 (2016).

15 Velasco A, Aburto-Medina A, Shahsavari E, Revah S, Ortiz I, Degradation mechanisms of DDX induced by the addition of toluene and glycerol as cosubstrates in a zero-valent iron pretreated soil. J Hazard Mater 321: 681-689 (2017). 
16 Song XJ, Chen ZH, Wang XM, Zhang SJ, Ligand effects on nitrate reduction by zero-valent iron: Role of surface complexation. Water Res 114: 218-227 (2017).

17 Noubactep C, An analysis of the evolution of reactive species in $\mathrm{Fe}^{0} / \mathrm{H}_{2} \mathrm{O}$ systems. $J$ Hazard Mater 168: 1626-1631 (2009).

18 Li JL, Bao HL, Xiong XM, Sun YK, Guan XH, Effective Sb(V) immobilization from water by zero-valent iron with weak magnetic field. Sep Purif Technol 151: 276-283 (2015).

19 Fan P, Sun Y, Qiao J, Lo IMC, Guan X, Influence of weak magnetic field and tartrate on the oxidation and sequestration of $\mathrm{Sb}$ (III) by zerovalent iron: Batch and semi-continuous flow study. J Hazard Mater 343: 266-275 (2017).

20 Dorjee P, Amarasiriwardena D, Xing BS, Antimony adsorption by zero-valent iron nanoparticles (nZVI): Ion chromatography-inductively coupled plasma mass spectrometry (IC-ICP-MS) study. Microchem J 116: 15-23 (2014).

21 Zhao XQ, Dou XM, Mohan D, Pittman CU, OK YS, Jin X, Antimonate and antimonite adsorption by a polyvinyl alcohol-stabilized granular adsorbent containing nanoscale zero-valent iron. Chem Eng J 6: 4268-4274 (2014).

22 Liu HW, Fu CY, Gu TY, Zhang GA, Lv YL, Wang HT, Liu HF, Corrosion behavior of carbon steel in the presence of sulfate reducing bacteria and iron oxidizing bacteria cultured in oilfield produced water. Corros Sci 100: 484-495 (2015).

23 Furukawa Y, Kim JW, Watkins J, Wilkin RT, Formation of ferrihydrite and associated iron corrosion products in permeable reactive barriers of zerovalent 
iron. Environ Sci Technol 36: 5469-5475 (2002).

24 Wilkin RT, Acree SD, Beak DG, Ross RR, Lee TR, Paul CJ, Field application of a permeable reactive barrier for treatment of arsenic in ground water. Report EPA 600/R-08/093, U.S. Environmental Protection Agency, Office of research and development, Washington, DC (2008).

25 An Y, Dong Q, Zhang KQ, Bioinhibitory effect of hydrogenotrophic bacteria on nitrate reduction by nanoscale zero-valent iron. Chemosphere 103: 86-91 (2014).

26 Liu HF, Zheng BJ, Xu DD, Fu CY, Luo Y, Effect of sulfate-reducing bacteria and iron-oxidizing bacteria on the rate of corrosion of an aluminum alloy in a central air-conditioning cooling water system. Ind Eng Chem Res 53: 7840-7846 (2014).

27 Wang H, Ju LK, Castaneda H, Cheng G, Newby BMZ, Corrosion of carbon steel C1010 in the presence of iron oxidizing bacteria Acidithiobacillus ferrooxidans. Corros Sci 89: 250-257 (2014).

28 Liu HW, Gu TY, Zhang GA, Liu L, The effect of magneticfield on biomineralization and corrosionbehavior of carbon steel induced by iron-oxidizing bacteria. Corros Sci 102: 93-102 (2016).

29 Solisio C, Lodi A, Converti A, Borghi MD, The effect of acid pre-treatment on the biosorption of Chromium(III) by Sphaerotilus natans from industrial wastewater. Water Res 34: 3171-3178 (2000).

30 Kondo K, Takeda M, Mashima T, Katahira M, Koizumi J, Ueda K, Conformational analysis of an extracellular polysaccharide produced by Sphaerotilus natans. 
Carbohyd Res 360: 102-108 (2012).

31 Starosvetsky J, Starosvetsky D, Pokroy B, Hilel T, Armon R, Electrochemical behaviour of stainless steels in media containing iron-oxidizing bacteria (IOB) by corrosion process modeling. Corros Sci 50: 540-547 (2008).

32 Caravelli AH, Giannuzzi L, Zaritzky NE, Reduction of hexavalent chromium by Sphaerotilus natans a filamentous micro-organism present in activated sludges. $J$ Hazard Mater 156: 214-222 (2008).

33 APHA-AWWA-WEF, Standard methods for examination of water and wastewater, 20th ed. American Public Health Association, Washington, DC (1998).

34 Tang S, Wang XM, Mao YQ, Zhao Y, Yang HW, Xie YF, Effect of dissolved oxygen concentration on iron efficiency: Removal of three chloroacetic acids. Water Res 73: 342-352 (2015).

35 Geng B, Jin ZH, Li TL, Qi XH, Kinetics of hexavalent chromium removal from water by chitosan-Fe ${ }^{0}$ nanoparticles, Chemosphere 75: 825-830 (2009).

36 Lefevre E, Bossa N, Wiesner MR, Gunsch CK, A review of the environmental implications of in situ remediation by nanoscale zero valent iron (nZVI): Behavior, transport and impacts on microbial communities. Sci Total Environ 565: 889-901 (2016).

37 Zhang WX, Nanoscale iron particles for environmental remediation: an overview. $J$ Nanopart Res 5: 323-332 (2003).

38 Wilson SC, Lockwood PV, Ashley PM, Tighe M, The chemistry and behaviour of This article is protected by copyright. All rights reserved. 
antimony in the soil environment with comparisons to arsenic: a critical review, Environ Pollut 158: 1169-1181 (2010).

39 Shi ZQ, Nurmi JT, Tratnyek PG, Effects of nano zero-valent iron on oxidation-reduction potential. Environ Sci Technol 45: 1586-1592 (2011).

$40 \mathrm{Yu}$ RF, Chi FH, Cheng WP, Chang JC, Application of pH, ORP, and DO monitoring to evaluate chromium(VI) removal from wastewater by the nanoscale zero-valent iron (nZVI) process. Chem Eng J 255: 568-576 (2014).

41 Yoon IH, Bang S, Chang JS, Kim MG, Kim KW, Effects of $\mathrm{pH}$ and dissolved oxygen on $\mathrm{Cr}(\mathrm{VI})$ removal in $\mathrm{Fe}(0) / \mathrm{H}_{2} \mathrm{O}$ systems. J Hazard Mater 186: 855-862 (2011).

42 Beolchini F, Pagnanelli F, Toro L, Vegliò F, Ionic strength effect on copper biosorption by Sphaerotilus natans: equilibrium study and dynamic modelling in membrane reactor. Water Res 40: 144-152 (2006).

43 Qin YC, Guan XH, Wang HT, Sorption of $\mathrm{Cu}^{2+}$ by Sphaeotilus natans and its biosorption mechanism. Acta Scientiae Circumstantiae 28: 892-896 (2008).

$44 \mathrm{Wu}$ HY, Chen WL, Rong XM, Cai P, Dai K, Huang QY, Adhesion to kaolinite and goethite of Pseudomonas putida at different growth phases. Chem Geol 390: 1-8 (2014).

45 Nghiem LD, Manassa P, Dawson M, Fitzgerald SK, Oxidation reduction potential as a parameter to regulate micro-oxygen injection into anaerobic digester for reducing hydrogen sulphide concentration in biogas. Bioresource Technol 173: 443-447 
(2014).

46 Bazrafshan H, Tesieh ZA, Dabirnia S, Touba RS, Manghabati H, Nasernejad B, Synthesis of novel $\alpha-\mathrm{Fe}_{2} \mathrm{O}_{3}$ nanorods without surfactant and its electrochemical performance. Powder Technol 308: 266-272 (2017).

47 Sheng JP, Baikenov MI, Liang XY, Rao XH, Ma FY, Su XT, Zhang Y, Rapid separation and large-scale synthesis of $\beta$-FeOOH nanospindles for direct coal liquefaction. Fuel Process Technol 165: 80-86 (2017).

48 Wan CC, Jiao Y, Qiang TG, Li J, Cellulose-derived carbon aerogels supported goethite $(\alpha-\mathrm{FeOOH})$ nanoneedles and nanoflowers for electromagnetic interference shielding. Carbohyd Polym 156: 427-434 (2017).

49 Chen YY, Furmann A, Mastalerz M, Schimmelmann A, Quantitative analysis of shales by KBr-FTIR and micro-FTIR. Fuel 116: 538-549 (2014).

50 Shen L, Ziheng J, Wang D, Wang YP, Lu YH, Enhance wastewater biological treatment through the bacteria induced graphene oxide hydrogel. Chemosphere 190: 201-210 (2017).

51 Li CY, Wang S, Du XP, Cheng XS, Fu M, Hou N, Li DP, Immobilization of ironand manganese-oxidizing bacteria with a biofilm-forming bacterium for the effective removal of iron and manganese from groundwater. Bioresource Technol 220: 76-84 (2016).

52 Sun Zhenya. Characterization and self-assembly synthesis of biomineralized nano-FeOOH and its environmental significance (Doctoral thesis). Wuhan: Wuhan 
University of Technology, 2006. in Chinese
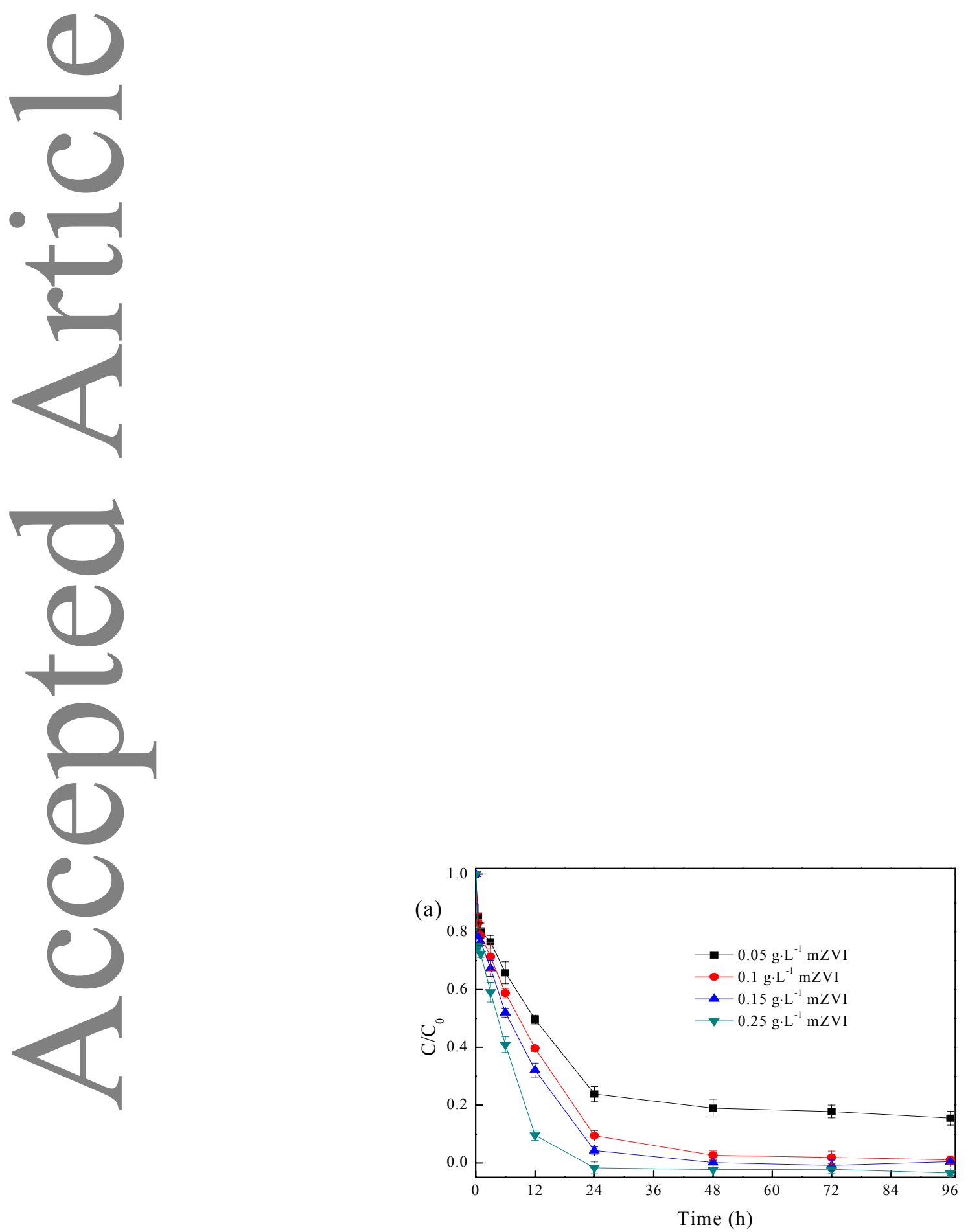

This article is protected by copyright. All rights reserved. 


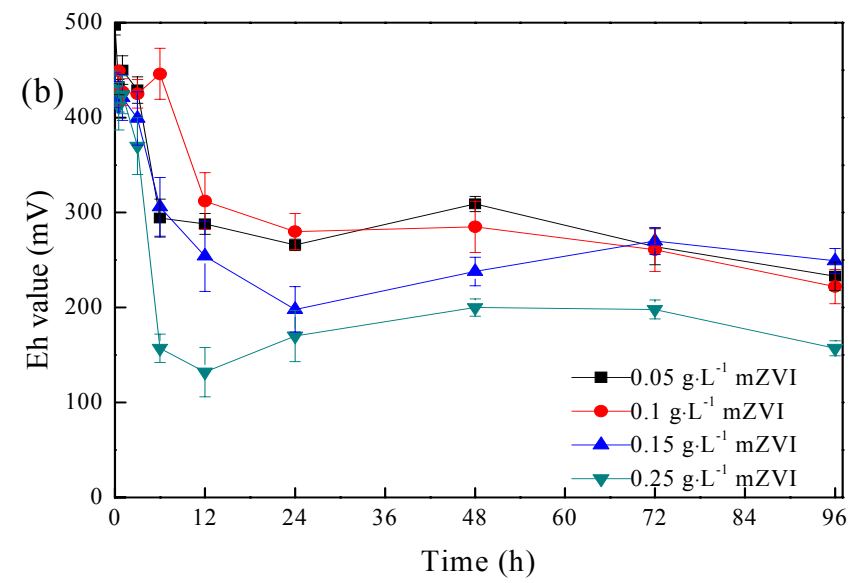

Figure 1. (a) ZVI adsorption ability towards $\mathrm{Sb}(\mathrm{V})$ in solution without purging with $\mathrm{N}_{2}$, and (b) the corresponding Eh value in solution as the reaction progressed.

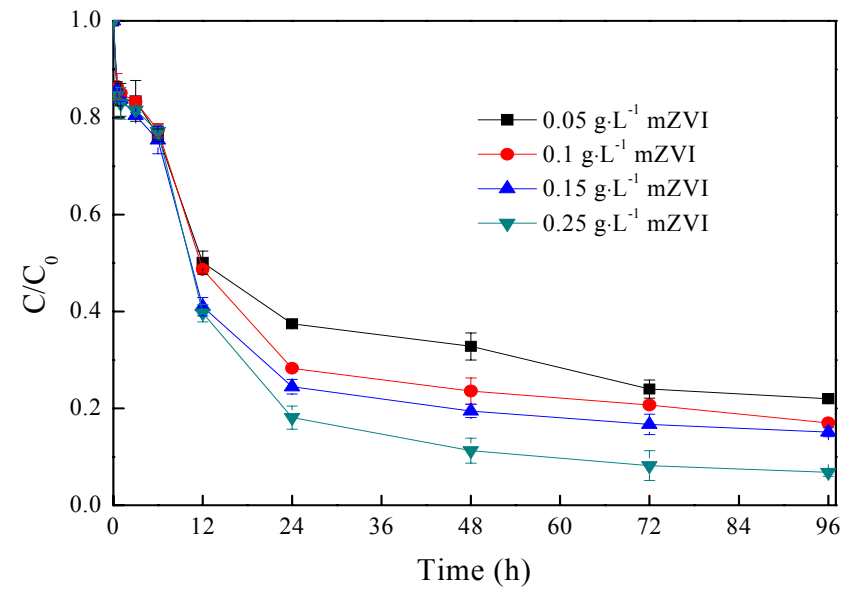

Figure 2. mZVI adsorption ability towards $\mathrm{Sb}(\mathrm{V})$ in solution after being purged with $\mathrm{N}_{2}$.

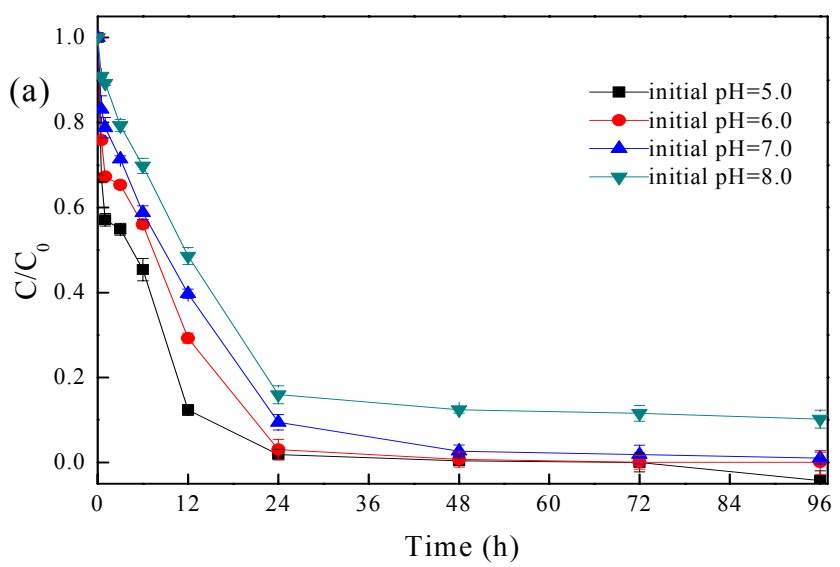




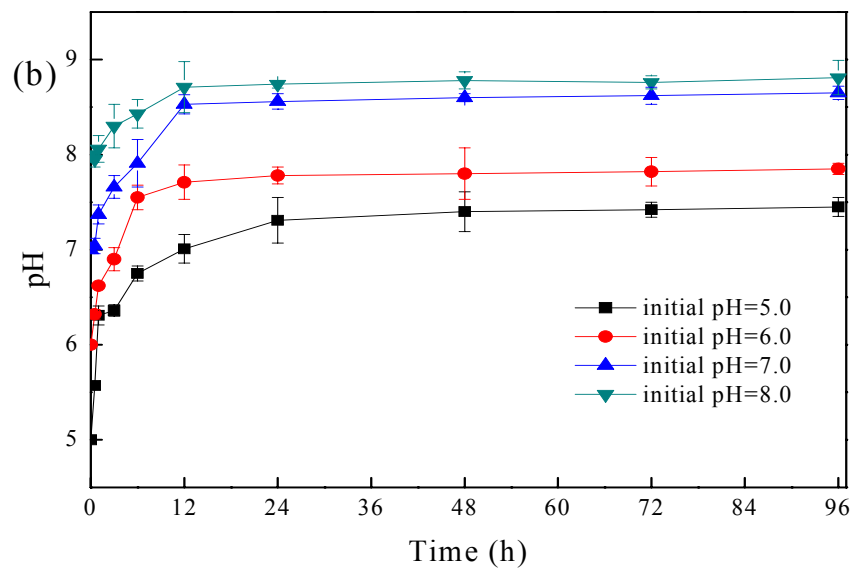

Figure 3. (a) Removal of $\mathrm{Sb}(\mathrm{V})$ from water with $\mathrm{ZVI}$ at different initial $\mathrm{pH}$, and (b) variation of $\mathrm{pH}$ values as the reaction progressed.

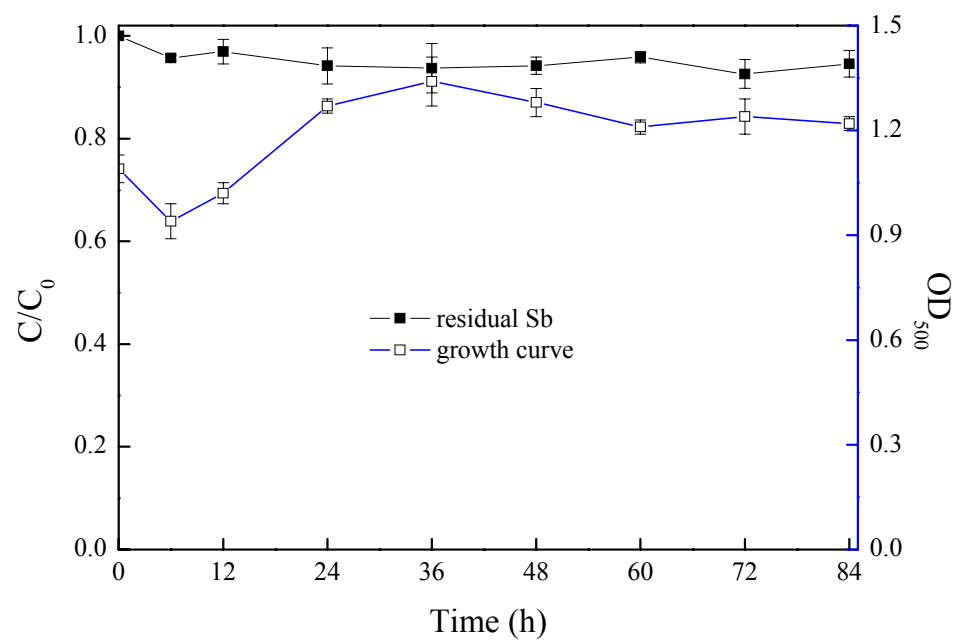

Figure 4. Bioadsorption ability of Sphaerotilus natans and its growth performance in $\mathrm{Sb}(\mathrm{V})$ solution.

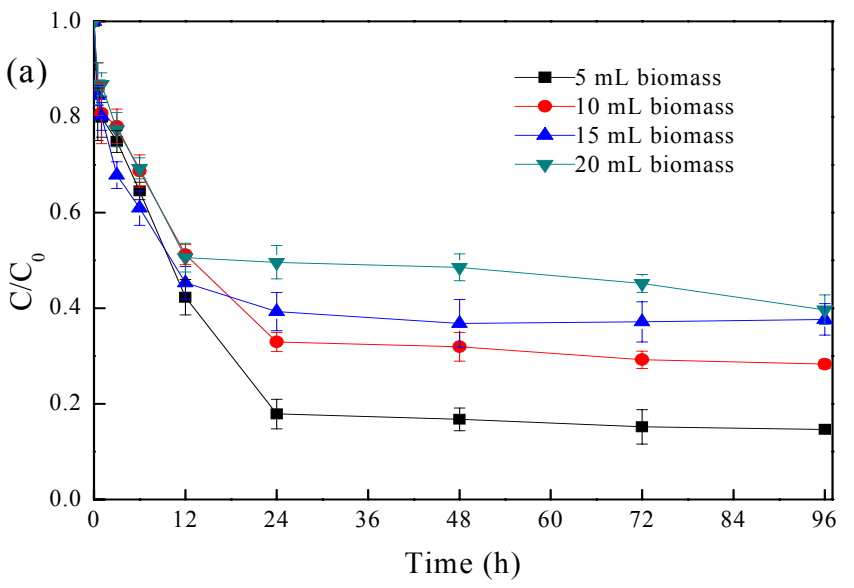

This article is protected by copyright. All rights reserved. 

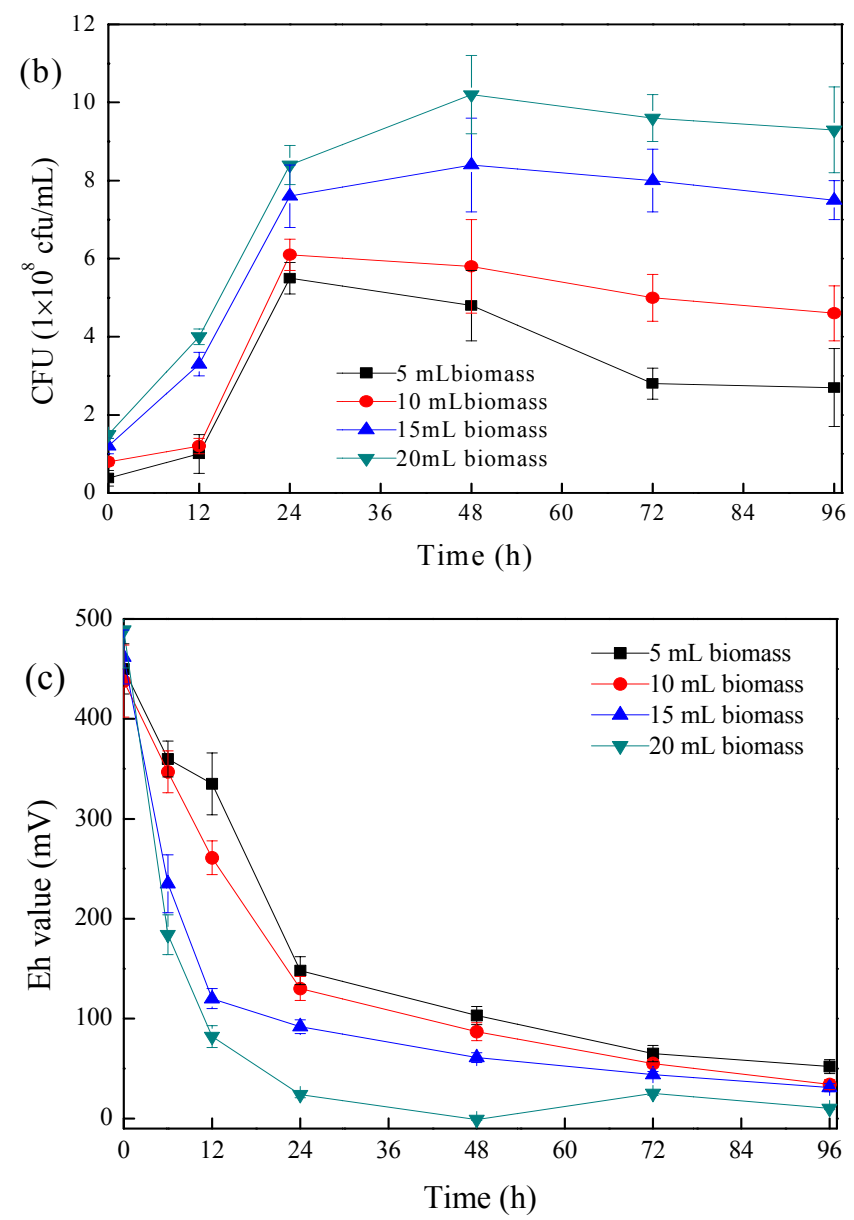

Figure 5. (a) $\mathrm{Sb}(\mathrm{V})$ removal of ZVI in the presence of Sphaerotilus natans, and changes of (b) the number of CFU and (c) Eh value in solution as the reaction progressed.
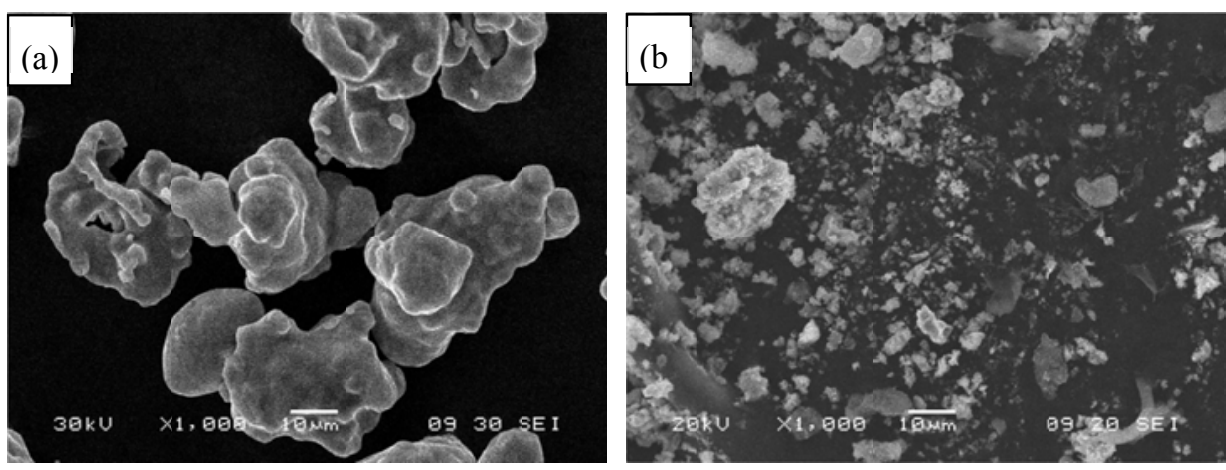

(c)

(d) 

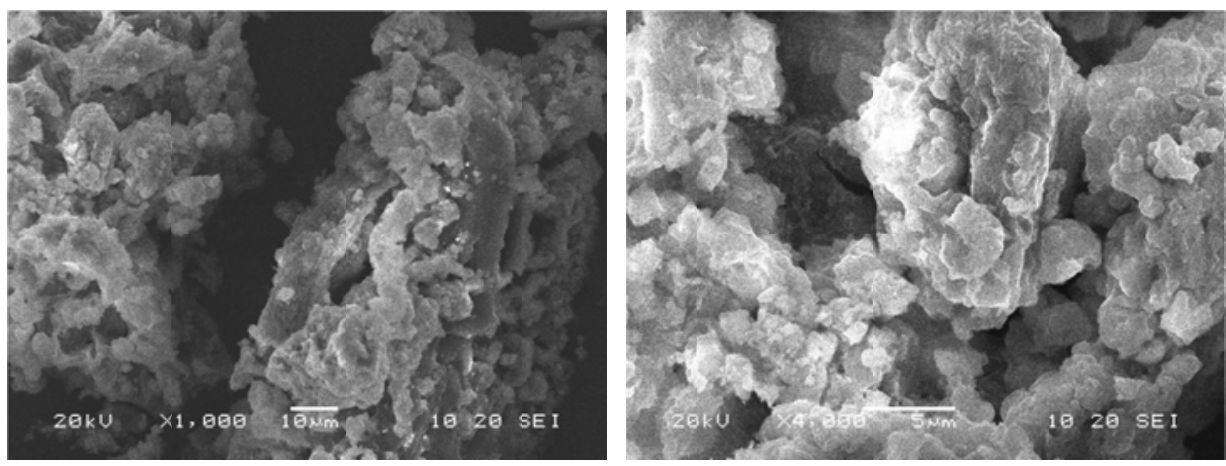

Figure 6. SEM images of (a) mZVI before reaction, (b) generated precipitate from reaction system without the presence of Sphaerotilus natans, and (c, d) product from reaction system with the presence of Sphaerotilus natans.
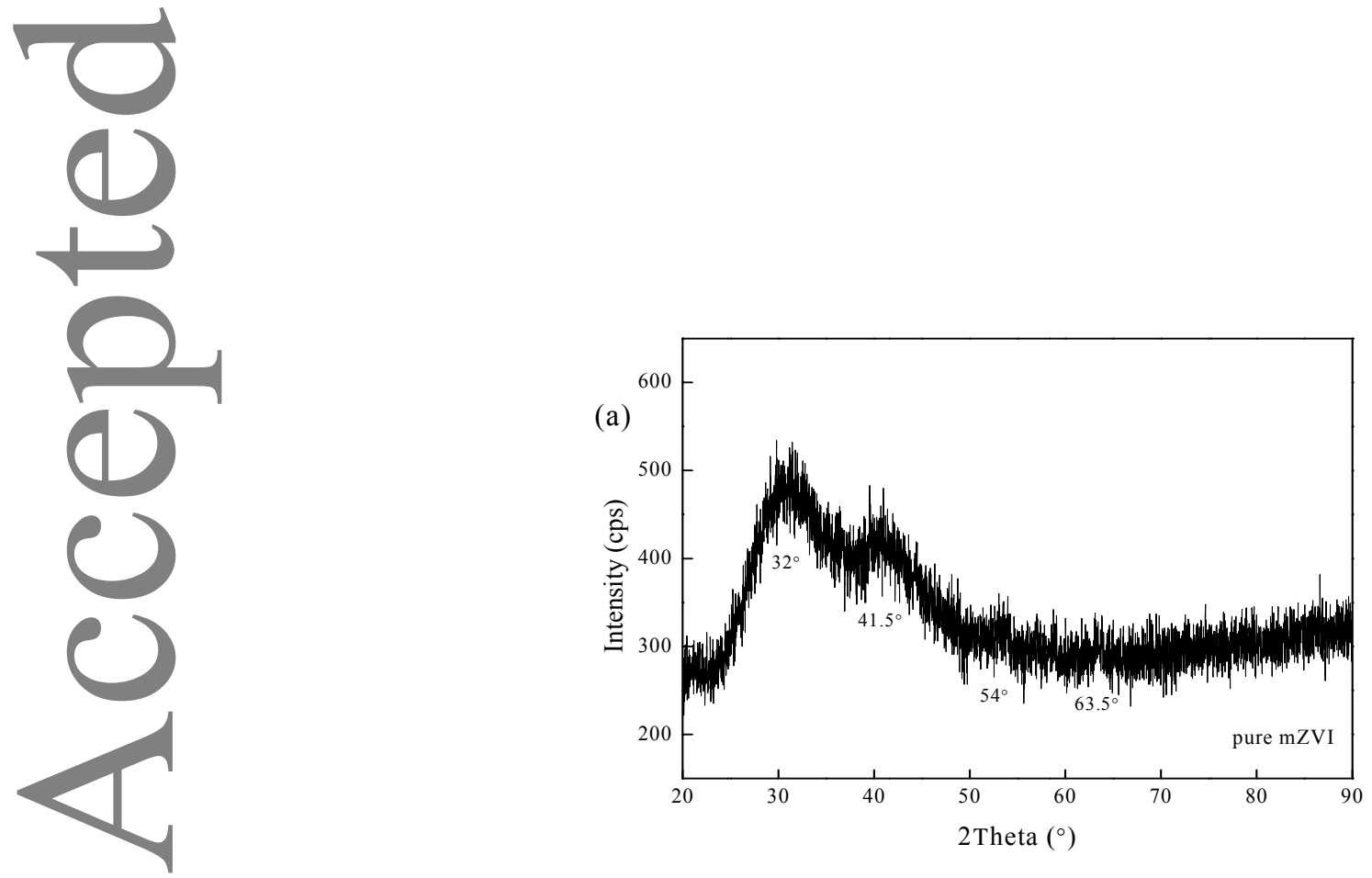


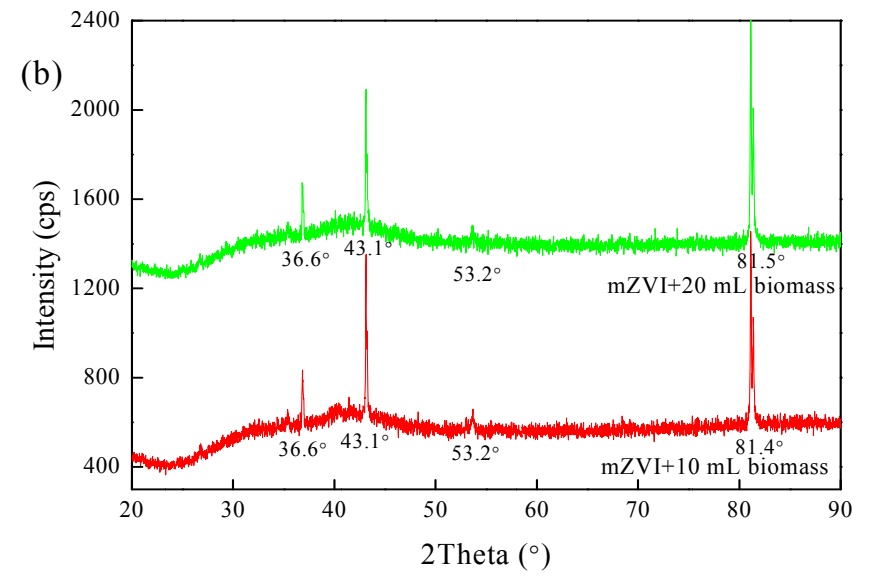

Figure 7 XRD patterns of product obtained from (a) the abiotic system and (b) biological system.

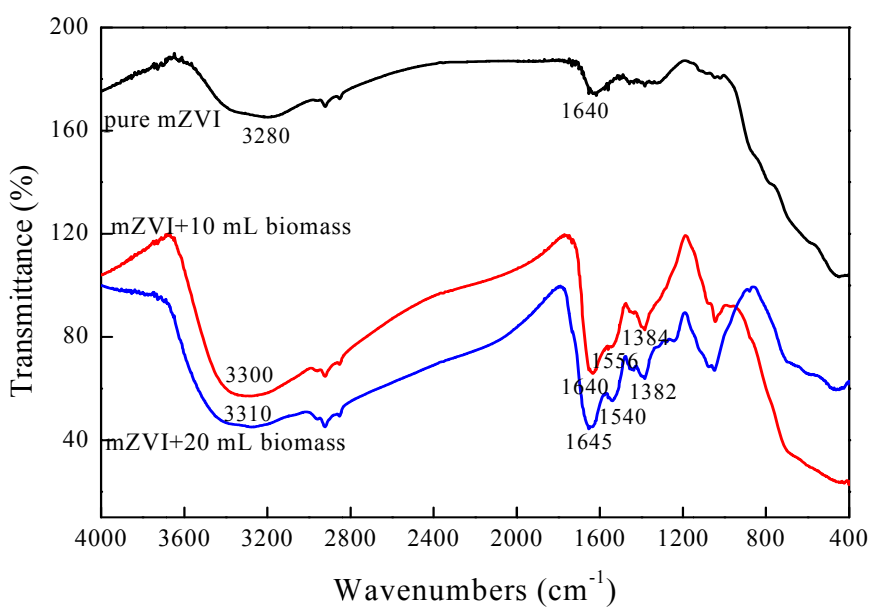

Figure 8. FTIR spectra of product obtained from the abiotic and biological system.

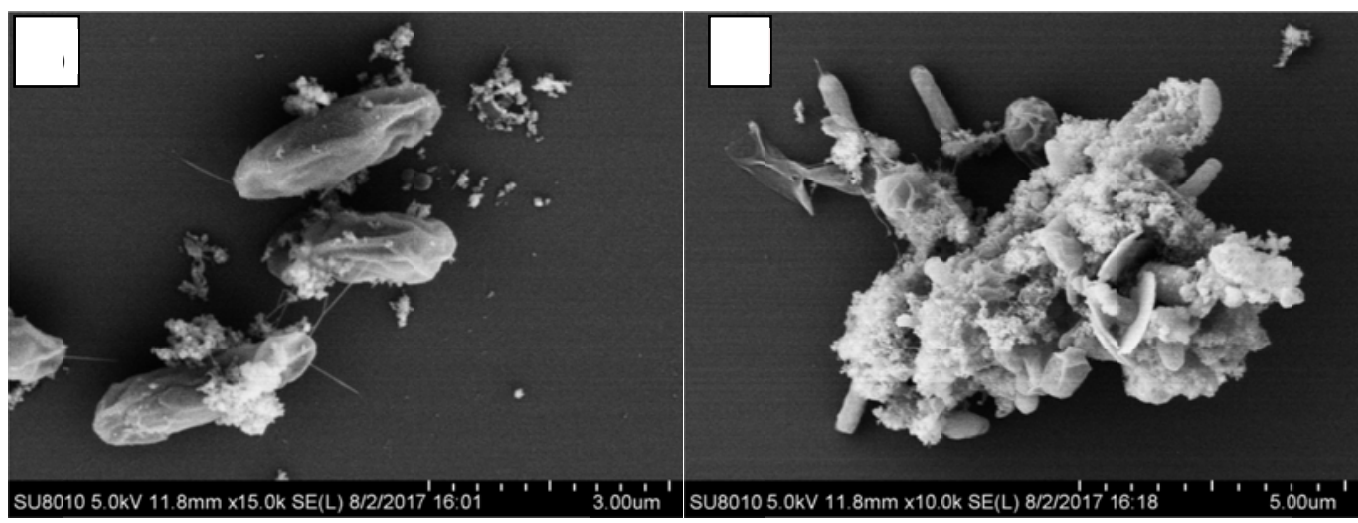

Figure 9. (a, b) HRSEM images of Sphaerotilus natans in biological system after reaction. 


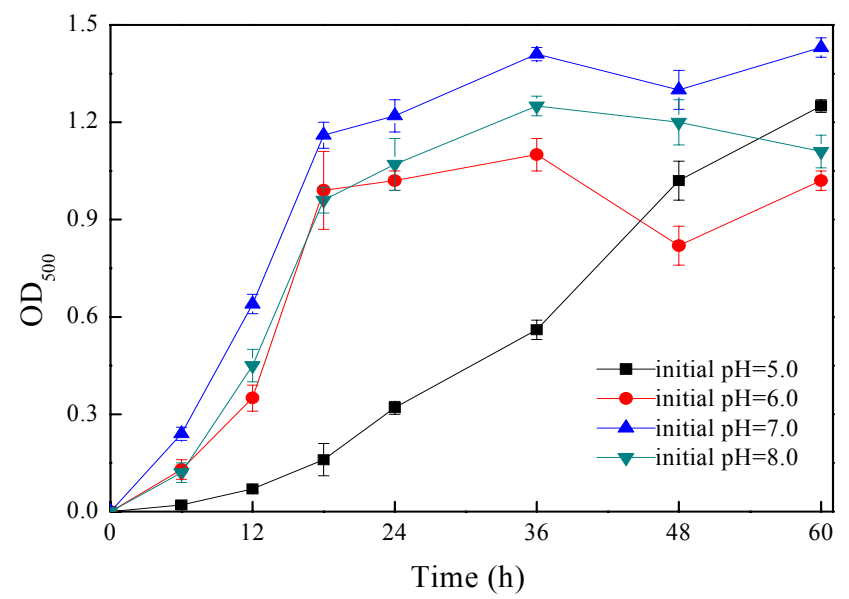

Figure S1 Growth curve of Sphaerotilus natans at different starting $\mathrm{pH}$ values. 